\title{
Distribution and fluxes of dissolved organic carbon in the Arctic Ocean \\ carbon
}

\author{
Alexander Vetrov \& Evgeny Romankevich \\ Shirshov Institute of Oceanology, Russian Academy of Sciences, Moscow, Russia
}

\begin{abstract}
Dissolved organic carbon, from marine biota excretions and decomposing detritus, is one of the main components of the carbon cycle in the ocean. In this study, an attempt was made to construct maps of the distribution and fluxes of DOC in the Arctic Ocean and the exchanges with the Pacific and Atlantic Oceans. Because of the limited data available a multiple linear regression technique was performed to identify significant relationships between DOC (2200 samples) and hydrologic parameters (temperature and salinity), as well as depth, horizon, latitude and offshore distance. Mapping of the DOC distribution and its fluxes was carried out at 38 horizons from 5 to $4150 \mathrm{~m}$ depth (resolution $1^{\circ} \times 1^{\circ}$ ). Data on temperature, salinity and meridional and zonal components of current velocities were obtained from the Ocean Re-Analysis System 4 (ORAS4) database. All these parameters were averaged for the JuneOctober period, the season of water sampling. The import of DOC in the Arctic

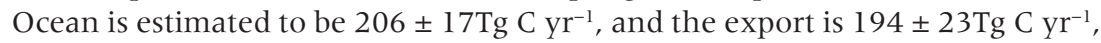
so the import-export is balanced within the errors.
\end{abstract}

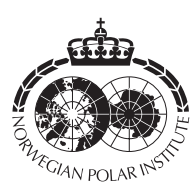

Keywords:

DOC fluxes; ocean carbon cycle; Pacific Ocean; Atlantic Ocean; Fram Strait

\section{Correspondence}

Alexander Vetrov, Shirshov Institute of Oceanology, Russian Academy of Sciences, 36, Nakhimovskiy Prospekt, 117997 Moscow, Russia.E-mail: vetrov@ocean.ru

\section{Abbreviations}

DOC: dissolved organic carbon; DOM: dissolved organic matter; ORAS4: Ocean Reanalysis System 4; RMSE: root-meansquared error; tDOC: terrigenous DOC; T-S: temperature-salinity

To access the supplementary material, please visit the article landing page

\section{Introduction}

Organic carbon in living substances and its decomposition products are the most mobile and labile forms of carbon participating in biosphere circulation. Organic carbon simultaneously occurs in different aggregate and dispersed states that transform into each other under the influence of physicochemical, biological and geological factors. In the ocean, the mass of DOC is 250 times higher than the mass of marine flora and fauna organic carbon and 20 times higher than that of particulate organic carbon. Dissolved organic matter serves as a substrate for bacteria and phytoplankton. The content and fluxes of DOC reflect the biogeochemical conditions in the sea, processes of organic matter synthesis and destruction, and propagation and spreading of waters. Dissolved organic carbon fluxes are tightly associated with oceanic thermohaline circulation. Many articles have been devoted to studying DOC distribution and fluxes in the Arctic Ocean (Amon 2004; Vetrov \& Romankevich 2004; Kivimae et al. 2010; Letscher et al. 2011; Anderson \& Amon 2015, etc.), but there is no general understanding of DOC fluxes at various depths.

In this paper, an attempt was made to construct maps of the distribution and fluxes of DOC in the Arctic Ocean and the exchange with adjacent water areas-the Pacific and Atlantic oceans. This work is based on data of water exchange and DOC concentrations in various water masses.

\section{Materials and methods}

The analysis of DOC distribution in the Arctic Ocean was based on 2200 samples, including data from the authors, which were obtained from the CARBON (Shirshov Institute of Oceanology, Russian Academy of Sciences) and PANGAEA (Alfred Wegener Institute, Helmholtz Center for Polar and Marine Research and the Center for Marine Environmental Sciences, University of Bremen) databases (see Supplementary Table S1). All data points were measured by hightemperature combustion. 

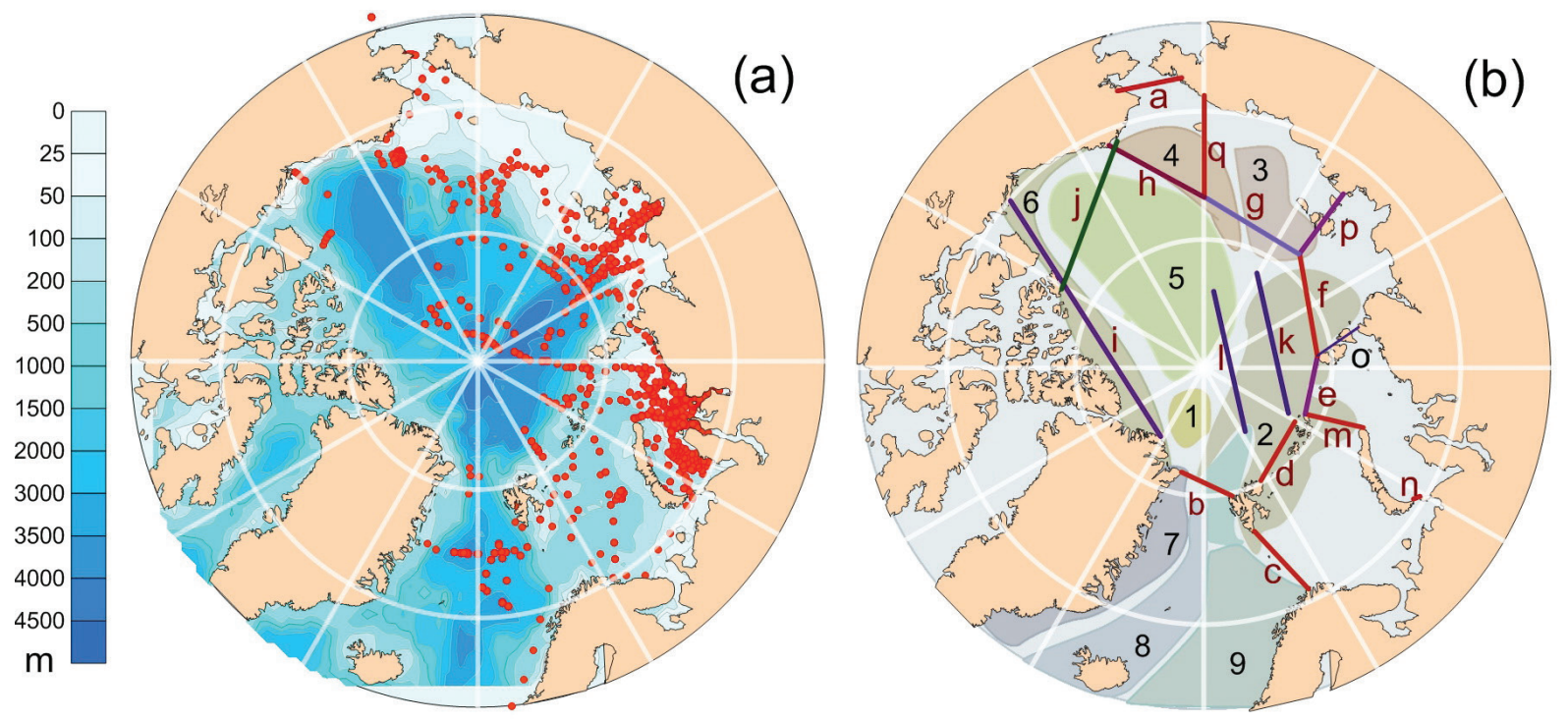

Fig. 1 Maps showing the (a) sampling points and (b) section locations. Colour shading in (b) shows the physiographic provinces of the Arctic Basin as classified by Gorškov et al. (1980) in accordance with the types of temperature-salinity diagrams: Spitsbergen (1), Severnaya Zemlya (2), New Siberian (3), Wrangel Island (4), Canadian (5), Canadian-Greenland (6), East Greenland (7), Greenland (8), Scandinavian (9). Sections: Bering Strait (a), Fram Strait (b), Nordkapp-Sørkapp (c), Barents Sea (d), Kara Sea (e), Laptev Sea (f), East Siberian Sea (g), Chukchi Sea (h), Canada Arctic Archipelago (i), Beaufort Gyre (j), Kara and Laptev seas (k), Poleward (1), Barents-Kara seas (m), Kara Gate (n), Kara-Laptev seas (o), Laptev-East Siberian seas (p), East Siberian-Chukchi seas (q).

Observational data coverage of the Arctic Ocean is extremely uneven (Fig. la). Extrapolating DOC to poorly sampled areas, which is necessary for mapping, required an analysis of the spatial water mass structure in the Arctic Ocean, which is the most complicated of the World Ocean. The Atlantic and Pacific waters form a system of currents that partially mix with Polar Water and transfer heat. These powerful water masses create stratification that varies in different areas and forms new water masses. Stratification depends strongly on river discharge into the Arctic Ocean, whose volume is approximately 10\% of the total supply to the World Ocean at a water mass ratio of 1:100. Over the shelves of the shallow Kara and Laptev seas, seasonal changes in water structure are most intense. Mixing of upper layers occurs during autumn cooling of surface waters, and brine release occurs during sea-ice formation over the Siberian Shelf seas. As a result, upper halocline water and deep water are formed and persist throughout the year.

As a basis for the analysis of the hydrological conditions and the organization of the data array of DOC and its fluxes, we adopted the structure of the ORAS4 database (Integrated Climate Data Center; http://icdc.cen. uni-hamburg.de/las) containing the results of model calculations for temperature and salinity and meridional and zonal components of current velocities for each month from 1958 to 2018 at 38 depths from 5 to $4155 \mathrm{~m}$ in the Arctic Ocean with a resolution of $1^{\circ} \times 1^{\circ}$.
Analysis of the ORAS4 simulation results showed that the velocity and direction of currents in the Arctic are subject to large seasonal and interannual variations resulting from changes in the ice cover, river runoff and wind. Given that all DOC data were obtained in the summer period, the data on temperature, salinity and current velocities obtained from the ORAS4 database were averaged for June-October 2014 (resolution $1^{\circ} \times 1^{\circ}$ ) for further analysis.

As a basis for mapping the DOC distribution in the Arctic Ocean, a multiple linear regression technique was adopted, predicting DOC as a function of independent variables such as temperature $(\mathrm{T})$, salinity $(\mathrm{S})$, horizon $(\mathrm{H})$, depth (E), latitude (La), longitude (Lo) and offshore distance $(\mathrm{D})$ :

$$
\begin{aligned}
\text { DOC }= & \text { Intercept }+\mathrm{a} \cdot \mathrm{D}+\mathrm{b} \cdot \mathrm{LO}+\mathrm{c} \cdot \mathrm{La}+\mathrm{d} \cdot \mathrm{E}+\mathrm{e} \cdot \\
& \mathrm{H}+\mathrm{f} \cdot \mathrm{T}+\mathrm{g} \cdot \mathrm{S},
\end{aligned}
$$

where a, b, c, etc. are regression coefficients. In the absence of data on salinity and temperature associated with DOC measurements, the ORAS4 S and T were used for the respective month and year. In a number of cases, the smallest RMSE values were obtained when only a subset of the independent variables were used in the multiple linear regression. To develop our DOC algorithms, we used the Statistica 8 programme. A total of 38 regression equations were developed for physiographic 
provinces (Fig. 1b), following the definition by Gorškov et al. (1980), as these have different T-S diagrams. The data of many of these provinces were subdivided according to the vertical structure of water masses or to the origin of water (Polar Water, halocline water, Atlantic Water, Pacific Water, deep water and bottom water). The mapped $\left(1^{\circ} \times 1^{\circ}\right)$ DOC distribution (Fig. 2) was calculated using gridded data of monthly temperature and salinity averaged over the summer period (June-October 2014, ORAS4). The values for coefficients a, b, c, etc. with standard error and statistics are listed in Supplementary Table S2. The errors of predicted DOC do not exceed 25\% in $70 \%$ of the cases as evaluated from the RMSE values.

The maps of DOC fluxes in the Arctic Ocean were created using meridional $(\mathrm{M})$ and zonal $(\mathrm{Z})$ components of current velocities in 2014 (ORAS4 database), averaged for June-October (Fig. 3). The DOC flux (F) was determined as $\mathrm{F}=\mathrm{DOC} \cdot \mathrm{R}$, where $\mathrm{R}=\left(\mathrm{M}^{2}+\mathrm{Z}^{2}\right)^{1 / 2}$ is the current velocity. The direction of the streams (geodesic azimuth) was calculated with the expression azimuth = $\operatorname{arctg}(\mathrm{Z} / \mathrm{M})$.

\section{Results and discussion}

The calculated DOC fluxes ranged from 0 to $0.2 \mathrm{~g} \mathrm{~m}^{-2} \mathrm{~s}^{-1}$. The maps reflect the tendency of reducing DOC fluxes with increasing depth, so the highest fluxes were in the shelf region. High fluxes of DOC in the areas of sea-river interfaces-in the influence areas of the Lena, $\mathrm{Ob}$ and Yenisei Rivers-and farther DOC transport were most clearly traced in maps of DOC distribution and in flux maps (Figs. 2, 3). The pronounced Beaufort Gyre and well-defined flux in the area of the East Greenland Current were demonstrated (Fig. 3). There were relatively high DOC lateral fluxes with Pacific and Atlantic waters. In particular, high DOC fluxes were found in the Nordic seas adjacent to the Arctic Ocean. Thus, the approach, calculations and model scenarios are well confirmed by field observations.

To assess the balance of the carbon cycle, we estimated DOC fluxes through sections a through q (Figs. 1, 4). The flux was considered positive if directed to the Arctic Ocean or towards the eastern boundary between the seas.
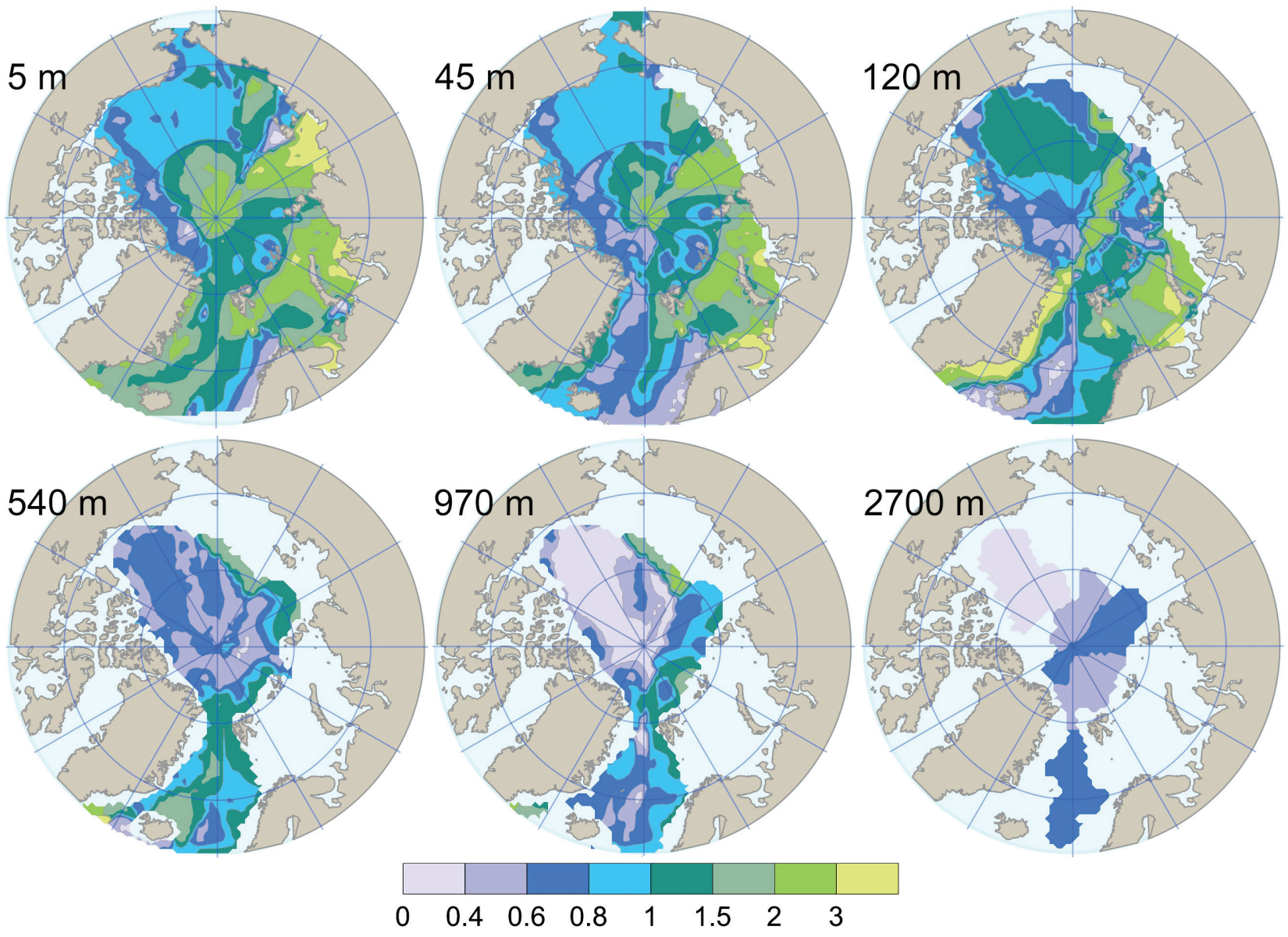

Fig. 2 Examples of DOC distributions averaged over June-October constructed at 38 depths from 5 to $4156 \mathrm{~m}^{(\mathrm{mg} \mathrm{L}} \mathrm{L}^{-1}$ ). 

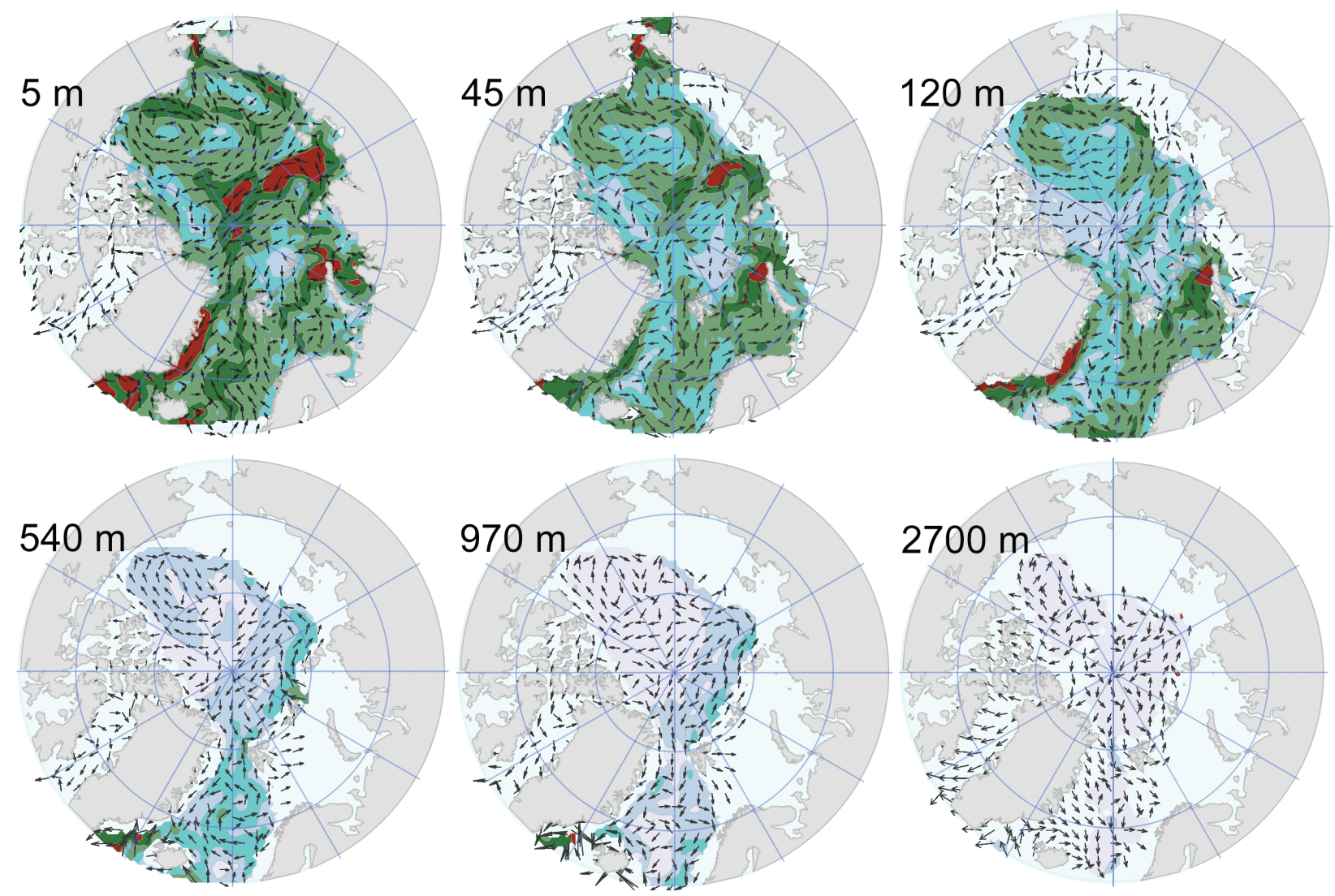

$\begin{array}{llllll}0.000 & 0.002 & 0.008 & 0.020 & 0.050 & 0.100\end{array}$

Fig. 3 Examples of calculated lateral DOC fluxes at depths of 5, 45, 120, 540, 968 and 2700 m averaged over June-October 2014. Colour shading shows the value of DOC flux $\left(\mathrm{g} \mathrm{m}^{-2} \mathrm{~s}^{-1}\right)$. The arrows show current directions. For clarity, only every third vector is drawn in the figure.

Given that all data on DOC were obtained in the summer period, the assessments of annual DOC fluxes are preliminary.

The estimation of DOC mass in the Arctic Ocean using the constructed maps yielded $8.05 \pm 1.4 \mathrm{Pg}$, which is $0.75 \%-1.0 \%$ of the DOC mass of $750-1000$ Pg in the World Ocean (Romankevich \& Vetrov 2016). The DOC mass in surface water (at depths of 0-35 m) was estimated to be $0.45 \pm 0.07 \mathrm{Pg}$; in subsurface water (at depths of $35-175 \mathrm{~m}), 1.1 \pm 0.16 \mathrm{Pg}$; in intermediate water (at depths of 175-750 m), $1.6 \pm 0.38 \mathrm{Pg}$; in deep water (at depths of 750-1200), $1.5 \pm 0.27 \mathrm{Pg}$; and in bottom water (at depths of $1200-4300 \mathrm{~m}$ ), $3.4 \pm 0.55 \mathrm{Pg}$. The corresponding average concentrations of DOC were $1.5 \pm 0.24$, $1.3 \pm 0.20,0.67 \pm 0.16,0.59 \pm 0.10$ and $0.60 \pm 0.10 \mathrm{mg}$ $\mathrm{L}^{-1}$. The average DOC concentration in the Arctic Ocean was estimated to be $0.69 \pm 0.16 \mathrm{mg} \mathrm{L}^{-1}$.

The estimates of volume transport were generally consistent with those published earlier (Table 1). The discrepancies did not exceed $25 \%$, except for fluxes through the Fram Strait $(0-700 \mathrm{~m},-0.1$ versus-1.4 Sv; -6 vs -40

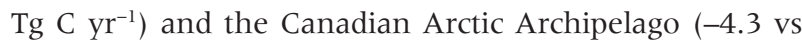
$-1.3 \mathrm{~Sv} ;-76 \mathrm{vs}-38{\mathrm{Tg} \mathrm{C} \mathrm{yr}^{-1}}^{-1}$. The total volume transport into Eurasian Arctic shelf seas (through the Bering Strait, the Nordkapp-Sørkapp section, the boundaries of the shelf seas with the Arctic Basin and the river runoff) was $10.8 \mathrm{~Sv}$, and the outflow was $9.93 \mathrm{~Sv}$ ( $8 \%$ imbalance). The corresponding DOC fluxes were estimated at $339 \pm 48$ and

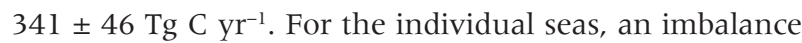
in the inflow and outflow of DOC appeared in the calculations as follows: $-22 \%$ in the Barents Sea, $36 \%$ in the Kara Sea, $-6 \%$ in the Laptev Sea, $-2 \%$ in the East Siberian Sea and $-17 \%$ in the Chukchi Sea. The assessment of the water balance and DOC budget of the individual shelf seas seems to be accompanied by large errors in the volume transport through rather narrow straits between the seas resulting from low resolution $\left(1^{\circ} \times 1^{\circ}\right)$. In the Barents and Chukchi seas, the DOC flux to the Arctic Basin was directly recompensed by the DOC, coming from the North Atlantic and the Bering Sea. In the Kara Sea, 

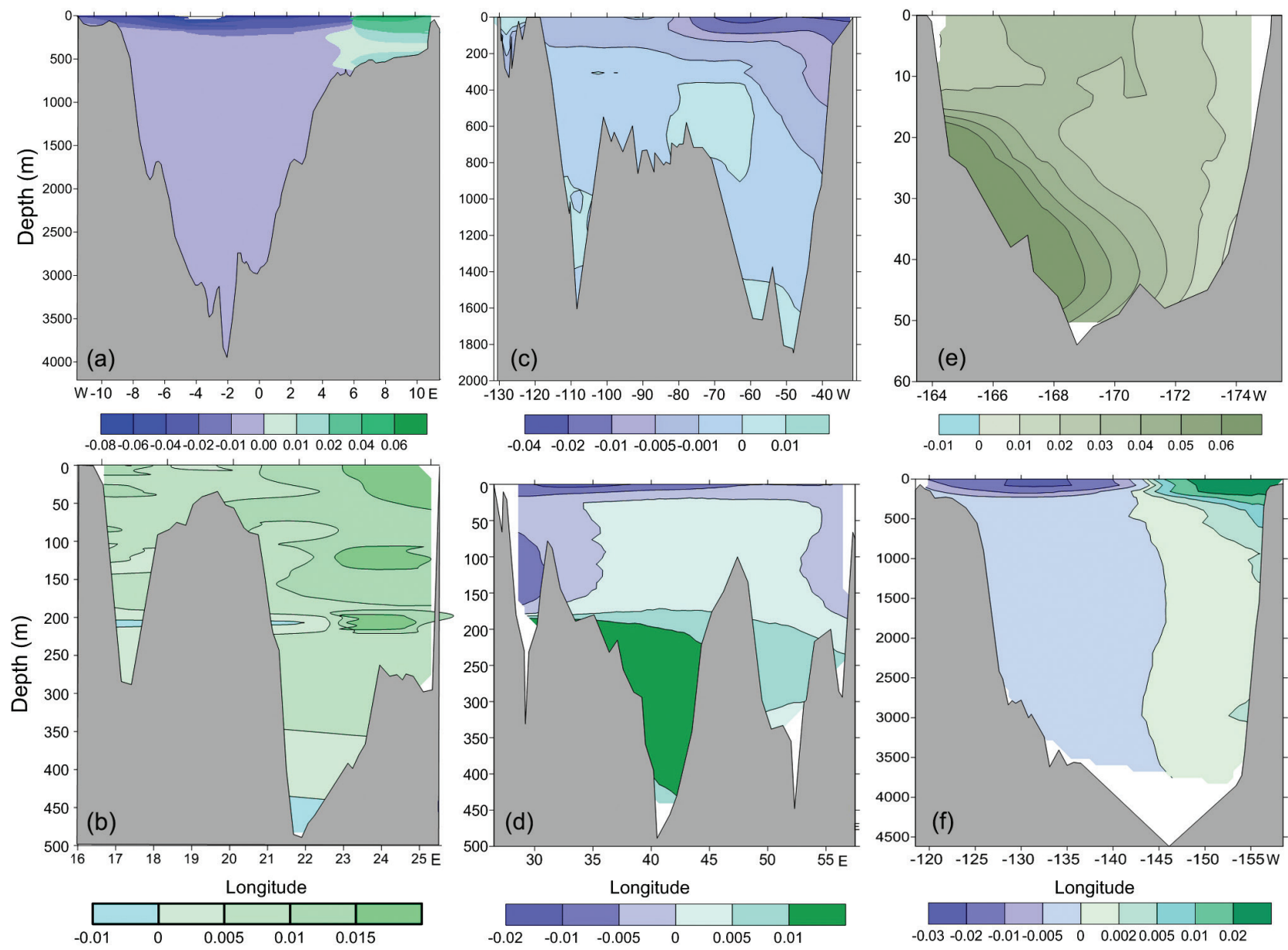

Fig. 4 Vertical distributions of DOC fluxes $\left(\mathrm{g} \mathrm{m}^{-2} \mathrm{~s}^{-1}\right)$ through the sections (see Fig. 1 for locations of the sections): (a) Fram Strait, section b; (b) Nordkapp-Sørkapp, section c; (c) Canadian Arctic Archipelago, section i; (d) Spitsbergen-Franz Josef Land, section d; (e) Bering Strait, section a; (f) Beaufort Gyre, section j. The sea bottom was created using IBCAO version 2.23 data with a resolution of 2 min (accessible as IBCAO_ver2_23_GEO_ ARC_2min.zip at https://www.ngdc.noaa.gov/mgg/bathymetry/arctic/grids/version2_23/; Jakobsson et al. 2008). The flux into the Arctic Ocean was considered positive.

the DOC balance could be achieved with the DOC flux

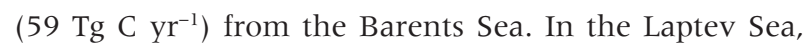

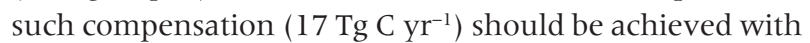
the Barents Sea waters. To compensate for DOC outflow,

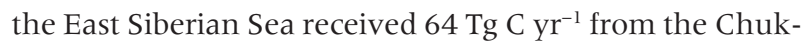
chi Sea and $13 \mathrm{Tg} \mathrm{C} \mathrm{yr}^{-1}$, possibly coming with Barents Sea waters. In contrast to volume transport, full balance of DOC fluxes is not the norm because of biogeochemical transformation of organic matter.

The general imbalance for inflow-outflow water in the Arctic Ocean is $-10 \%$. The observed imbalance may be an effect caused by the low spatial and temporal resolution of the constructions, and delayed return of the Atlantic waters for four to six years with changes in water circulation, which depend on the atmospheric circulation. In the period of anticyclonic circulation, freshened waters accumulate in the Canadian Basin, while during cyclonic circulation, these waters flow into the Fram Strait and the Canadian Arctic Archipelago (Kuzin et al. 2012).

The import of DOC in the Arctic Ocean was estimated to be $206 \pm 17 \mathrm{Tg} \mathrm{C} \mathrm{yr}^{-1}$, and the export $194 \pm$ $23 \mathrm{Tg} \mathrm{C} \mathrm{yr}^{-1}$, differing from other researchers' estimates of 282 and $264 \mathrm{Tg} \mathrm{C} \mathrm{yr}^{-1}$ (Amon 2004) and $253 \pm 14$ and $244 \pm 14 \mathrm{Tg} \mathrm{C}_{\mathrm{yr}}{ }^{-1}$, respectively (Anderson \& Amon 2015). According to our estimates, the import of DOC in the Arctic Ocean at $12 \pm 17 \operatorname{Tgyr}^{-1}(6 \%)$ exceeded export into the Atlantic Ocean.

The discrepancy in estimated DOC fluxes through the Fram Strait is primarily a result of the estimates of volume flux. The inflow and outflow of water through the Fram Strait(1.8 vs-3.5 Sv), which we calculated using 
Table 1 Volume transport (Sv) and DOC fluxes (Tg C yr-1) through the sections (see Fig. 1 for locations of sections).

\begin{tabular}{|c|c|c|c|c|c|c|c|c|}
\hline \multirow[t]{2}{*}{ Section } & \multicolumn{4}{|c|}{ Volume transport $\left(10^{6} \mathrm{~m}^{3} \mathrm{~s}^{-1}=1 \mathrm{~Sv}\right)$} & \multicolumn{4}{|c|}{ DOC flux (Tg C $\left.y r^{-1}\right)$} \\
\hline & $\ln$ & Out & $\Sigma$ & Ref. & In & Out & $\Sigma$ & Ref. \\
\hline a & 0.9 & 0.0 & 0.9 & $0.83^{a}$ & 25 & 0 & $25 \pm 2$ & $22^{\mathrm{a}}$ \\
\hline$b$ & 1.8 & -3.5 & -1.7 & $-2.08^{8}$ & 50 & -101 & $-50 \pm 11$ & \\
\hline 0-700 m & 1.8 & -1.9 & -0.1 & $-1.4^{c}$ & 50 & -56 & $-6 \pm 1$ & -40 \\
\hline$>700 \mathrm{~m}$ & 0.0 & -1.6 & -1.6 & $-2.2^{c}$ & 1.0 & -45 & $-44 \pm 9$ & -34 \\
\hline c & 3.8 & 0.0 & 3.8 & $3.27^{c, d}$ & 92 & 0 & $92 \pm 13$ & $80^{d}$ \\
\hline$d$ & 0.63 & -0.12 & 0.5 & $0.36^{d}$ & 16 & -4.0 & $12 \pm 6$ & $10^{d}$ \\
\hline e & 3.1 & -0.1 & 3.1 & & 72 & -2.0 & $70 \pm 22$ & \\
\hline I & 3.9 & -4.2 & -0.3 & & 157 & -135 & $22 \pm 7$ & \\
\hline g & 1.7 & -0.11 & 1.6 & & 81 & -4.0 & $77 \pm 12$ & \\
\hline h & 0.6 & -1.57 & -1.0 & & 15 & -52 & $-37 \pm 3$ & \\
\hline i & 0.7 & -5.0 & -4.3 & $-1.3^{f}$ & 13 & -89 & $-76 \pm 3$ & $-38^{i}$ \\
\hline j & 7.2 & -6.9 & 0.3 & & 159 & -147 & $12 \pm 3$ & \\
\hline k & 7.2 & -1.9 & 5.3 & & 282 & -60 & $221 \pm 89$ & \\
\hline $0-600 \mathrm{~m}$ & 3.9 & -0.9 & 3.0 & & 160 & -31 & $129 \pm 53$ & \\
\hline 1 & 9.0 & -0.3 & 8.7 & & 360 & -7 & $353 \pm 90$ & \\
\hline $0-600 \mathrm{~m}$ & 5.0 & 0 & 5.0 & & 206 & -3 & $203 \pm 50$ & \\
\hline Ice & 0 & $-0.09^{b}$ & -0.09 & $-0.09^{b}$ & 0 & $-3.8^{e}$ & $-3.8 \pm 3$ & $-3.8^{\mathrm{e}}$ \\
\hline Rivers & $0.12^{\mathrm{j}}$ & 0 & 0.12 & $0.12^{\mathrm{j}}$ & $25^{i}$ & 0 & $25 \pm 2$ & $25^{i}$ \\
\hline \multirow[t]{2}{*}{ In/out ${ }^{k}$} & 7.32 & -8.60 & -1.28 & & $206 \pm 17$ & $-194 \pm 23$ & $12 \pm 17$ & $9^{i}$ \\
\hline & To east & To west & & & To east & To west & & \\
\hline $\mathrm{m}$ & 3.3 & -0.4 & 2.9 & $2.5^{d}$ & 125 & -14 & $111 \pm 44$ & $60^{d}$ \\
\hline$n$ & 0.1 & 0.0 & 0.10 & $0.32^{h}$ & 6 & 0 & $6 \pm 2$ & $10^{d}$ \\
\hline 0 & 0.37 & -0.07 & 0.3 & & 6 & -3 & $3 \pm 1$ & \\
\hline$p$ & 0.01 & -0.15 & -0.1 & & 0 & -5 & $-5 \pm 1$ & \\
\hline$q$ & 0.0 & -2.6 & -2.6 & & 0 & -80 & $-80 \pm 4$ & \\
\hline
\end{tabular}

${ }^{a}$ Cai et al. 2014. ${ }^{b}$ Eicken 2004. ${ }^{\mathrm{C}}$ Fahrbach et al. 2001. ${ }^{\mathrm{d}}$ Kivimae et al. 2010. ${ }^{\mathrm{e}} \mathrm{Amon}$ 2004. ${ }^{\mathrm{f}}$ Lundberg \& Haugan 1996. ${ }^{\mathrm{g}}$ Mauritzen et al. 2011. ${ }^{\mathrm{h}} \mathrm{Maslowski}$ et al. 2004. 'Anderson \& Amon 2015. 'Manizza et al. 2009. ${ }^{~}$ In/out Arctic Ocean ( $a+b+c+i+i c e+$ rivers).

the current velocities from the ORAS4 model, is lower than that of 4.9 and-8.1 Sv taken from the literature (Anderson \& Amon 2015). Large interannual variations in the net volume flux through the Fram Strait (between -4.7 and-0.3 Sv)exist (Beszczynska-Moller et al. 2011). Displacing our section $b$ from the narrowest part of the Fram Strait to the $78.8^{\circ} \mathrm{N}$ parallel, where measurements of current velocities are usually made, did not result in significant changes in the volume flux (2.2 vs-3.8 Sv). Differences in the calculated concentrations of DOC are inevitable. In our case, the average DOC values for surface waters $(1.3-1.5 \mathrm{mg} / \mathrm{L})$ were higher than the $0.84-$ $0.95 \mathrm{mg} / \mathrm{L}$ from other calculations (Anderson \& Amon 2015), while for depths greater than $175 \mathrm{~m}$, the values were comparable.

The discrepancy in estimates of DOC fluxes through the Canadian Arctic Archipelago is also largely caused by different estimates of volume flux. Our calculations of the outflow through section i neighbouring the Canadian Arctic Archipelago gave a value of $-4.3 \mathrm{~Sv}$, which is high compared to other estimates. The estimated outflow through three main gateways of the Canadian Arctic
Archipelago-Nares Strait, Lancaster Sound and Cardigan Strait (plus Hell Gate)-is - $1.8 \pm 0.1$ Sv (Beszczynska-Moller et al. 2011). The outflow through Davis Strait, through which all or almost all the water entering these straits passes towards the North Atlantic, has been estimated from-1.6 to-3.6 Sv (Beszczynska-Moller et al. 2011).

Along with DOC entering the Arctic Ocean, DOM is supplied by phytoplankton and ice algae. Their production has been estimated at 182 and $44 \mathrm{Tg} \mathrm{C} \mathrm{yr}^{-1}$, respectively (Vetrov \& Romankevich 2014). If we assume approximately $20 \%$ of the production from phytoplankton and ice algae is realized into the water as metabolites (Myklestad 2000), the metabolite pro-

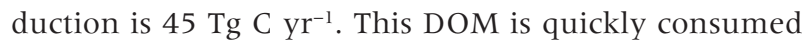
by bacteria.

The tDOC entering the ocean with river runoff is also bioavailable (Sipler et al. 2017). Subsequent reduction in tDOC with a first-order removal rate constant of $0.24 \pm 0.07 \mathrm{yr}^{-1}$ (Letscher et al. 2011) for the incoming water from the Eurasian rivers and $0.097 \mathrm{yr}^{-1}$ (Hansell et al. 2004) for that from the Mackenzie and 
Yukon rivers led to the removal of $4.8 \pm 1.3$ and ca. 0.3 Tgt DOC $\mathrm{yr}^{-1}$, respectively. The photodegradation of humic substances under sunlight plays an important role in the mineralization of tDOC (half decay of one to five years). As a result, low-molecular carbonyl compounds are formed, which are utilized by bacteria (Kieber et al. 1990). The share of tDOC in the surface waters of the East Greenland Current is estimated to be $9 \%-27 \%$ of DOC (Opsahl et al. 1999), and the calculated tDOC flux through the Fram Strait in the 0-200 m layer is $6 \pm 3 \mathrm{Tg} \mathrm{C} \mathrm{yr}^{-1}$. Considering that the share of tDOC in the Canadian Basin is approximately $6 \%$ of DOC (Opsahl et al. 1999), its flux through the straits of the Canadian Arctic Archipelago in the $0-200 \mathrm{~m}$ layer is $3.5 \pm 0.5 \mathrm{Tg}$ $\mathrm{C} \mathrm{yr}^{-1}$. The fraction of tDOC suspended in the marginal filters (because of flocculation) may be approximately $5 \%$ of DOC or approximately $2 \mathrm{Tg} \mathrm{C} \mathrm{yr}^{-1}$. Thus, $16 \pm 4$ Tgt DOC $\mathrm{yr}^{-1}$ is removed from the Arctic Ocean.

The DOM arriving from the conjugate oceans is mainly semi-labile terrigenous-planktonic organic matter, which has a lifetime of up to 200-500 years and a tDOC concentration of $0.02 \mathrm{mg} \mathrm{L}^{-1}$ (Amon \& Budéus 2003). The import of this DOM to the Arctic Ocean corresponding to our volume transport calculations is estimated at $178 \pm 15 \mathrm{Tg} \mathrm{C} \mathrm{yr} r^{-1}\left(155 \pm 13 \mathrm{Tg} \mathrm{C} \mathrm{yr}{ }^{-1}\right.$ from the North Atlantic and $23 \pm 2 \mathrm{Tg} \mathrm{C} \mathrm{yr}^{-1}$ from the

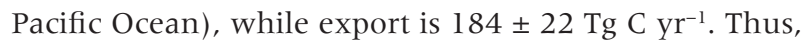
within the errors of measurements and calculations, the import-export fluxes of marine organic matter are generally balanced.

In general, our maps of DOC fluxes based on measured DOC concentrations and calculations of volume flux showed a good balance and a $6 \%$ prevalence of imports over exports, comparable to existing estimates. In our opinion, the greatest uncertainty is contributed by the small amount of data on DOC and its distribution by water mass and the absence of seasonal measurements. The western regions of the Arctic Ocean have the lowest measurement coverage. Significant difficulties arise in estimating the current velocities, and the current velocity directions and magnitudes are highly variable on seasonal and interannual scales. To clarify the fate of tDOC, making wider use of carbon isotopic compositions and biomarkers of the genesis of organic matter is necessary.

\section{Acknowledgements}

The authors thank the Integrated Climate Data Center for the T-S data and current velocities presented. The authors are grateful for the valuable comments of Are Olsen, two anonymous reviewers and translator W. Corine.

\section{Disclosure statement}

No potential conflict of interest was reported by the authors.

\section{Funding}

The sampling and measurement of DOC concentrations were obtained within the framework of the state assignment of the Shirshov Institute of Oceanology of the Russian Academy of Sciences, no. 0149-2019-0006. The results of generalization of available data and three-dimensional mapping were funded by the Russian Science Foundation, research project 16-05-00032.

\section{References}

Amon R.M.W. 2004. The role of dissolved organic matter for the Arctic Ocean carbon cycle. In R. Stein \& R.W. Macdonald (eds.): The organic carbon cycle in the Arctic Ocean. Pp. 83-99. Berlin: Springer.

Amon R.M.W., Budéus G. \& Meon B. 2003. Dissolved organic carbon distribution and origin in the Nordic seas: exchanges with the Arctic Ocean and the North Atlantic. Journal of Geophysical-Oceans Research 108, article no. 3221, http://dx.doi.org/10.1029/2002JC001594.

Anderson L.G. \& Amon R.M.W. 2015. DOM in the Arctic Ocean. In D.A. Hansell \& C.A. Carlson (eds.): Biogeochemistry of marine dissolved organic matter. Pp. 609-633. Calveston: Elsevier.

Beszczynska-Möller A., Woodgate R.A., Lee C., Melling H. \& Karcher M. 2011. A synthesis of exchanges through the main oceanic gateways to the Arctic Ocean. Oceanography 24, 82-99, http://dx.doi.org/10.5670/oceanog. 2011.59.

Cai W.-J., Bates N.R., Guo L., Anderson L.G., Mathis J.T., Wanninkhof R., Hansell D.A., Chen L. \& Semiletov I.P. 2014. Carbon fluxes across boundaries in the Pacific Arctic region in a changing environment. In J.M. Grebmeier \& W. Maslowski (eds.): The Pacific Arctic region: ecosystem status and trends in a rapidly changing environment. Pp. 199-222. Dordrecht: Springer.

Eicken H. 2004. The role of Arctic Sea ice in transporting and cycling terrestrial organic matter. In R. Stein \& R.W. Macdonald (eds.): The organic carbon cycle in the Arctic Ocean. Pp. 45-53. Berlin: Springer.

Fahrbach E., Meincke J., Østerhus S., Rohardt G., Schauer U., Tverberg V. \& Verduin J. 2001. Direct measurements of volume transport through the Fram Strait. Polar Research 20, 217-224, http://dx.doi.org/10.3402/polar. v20i2.6520.

Gorškov S.G., Alekseev V.N. \& Faleev V.I. (eds.) 1980. Atlas okeanov. Severnyj Ledovityj Okean. (Atlas of the oceans. The Arctic Ocean.) Moscow: Main Directorate of Navigation and Oceanography of the USSR Ministry of Defense. 
Hansell D.A., Kadko D. \& Bates N.R. 2004. Degradation of terrigenous dissolved organic carbon in the western Arctic Ocean. Science 304, 858-861, http://dx.doi.org/10.1126/ science.1096175.

Jakobsson M., Macnab R., Mayer L., Anderson R., Edwards M., Hatzky J., Schenke H.W. \& Johnson P. 2008. An improved bathymetric portrayal of the Arctic Ocean: implications for ocean modeling and geological, geophysical and oceanographic analyses. Geophysical Research Letters 35, article no. L07602, http://dx.doi.org/10.1029/2008GL033520.

Kieber R.J., Zhou X. \& Mopper K. 1990. Formation of carbonyl compounds from UV-induced photodegradation of humic substances in natural waters: fate of riverine carbon in the sea. Limnology and Oceanography 35, 1503-1515, http://dx.doi.org/10.4319/lo.1990.35.7.1503.

Kivimäe C., Bellerby R.G.J., Fransson A., Reigstad M. \& Johannessen T. 2010. Carbon budget for the Barents Sea. Deep-Sea Research Part 157, 1532-1542, http://dx.doi. org/10.1016/j.dsr.2010.05.006.

Kuzin V.I., Platov G.A., Golubeva E.N. \& Malahova V.V. 2012. $\mathrm{O}$ nekotory hresultatah čislennogo modelirovanija processov v Severnom Ledovitom Okeane. (Results of numerical simulation of processes in the Arctic Ocean.) Izvestija RAN, Fizika Atmosferyi Okeana 48, 117-136. Moscow: Nauka.

Letscher R.T., Hansell D.A. \& Kadko D. 2011 . Rapid removal of terrigenous dissolved organic carbon over the Eurasian shelves of the Arctic Ocean. Marine Chemistry 123, 78-87, http://dx.doi.org/10.1016/j.marchem.2010.10.002.

Lundberg L. \& Haugan P.M. 1996. Nordic seas-Arctic Ocean carbon budget from volume flows and inorganic carbon data. Global Biogeochemical Cycles 10, 493-510, http://dx. doi.org/10.1029/96GB00359.

Manizza M., Follows M.J., Dutkiewicz S., McClelland J.W., Menemenlis D., Hill C.N., Townsend-Small A. \& Peterson B.J. 2009. Modeling transport and fate of riverine dissolved organic carbon in the Arctic Ocean. Global Biogeochemical Cycles 23, GB4006, http://dx.doi.org/ 10.1029/2008GB003396.

Maslowski W., Marble D., Walczowski W., Schauer U., Clement J.L. \& Semtner A.J. 2004. On climatological mass, heat, and salt transports through the Barents Sea and Fram Strait from a pan-Arctic coupled ice-ocean model simulation. Journal of Geophysical Research-Oceans 109, C03032, http://dx.doi.org/10.1029/2001JC001039.

Mauritzen C., Hansen E., Andersson M. Berx B., Beszczynska-Moller A., Burud I., Christensen K.H., Debernard J., de Steur L., Dodd P., Gerland S., Godoy O., Hansen B., Hudson S., Hoydalsvik F., Ingvaldsen R., Isachsen P.E., Kasajima Y., Koszalka I., Kovacs K.M., Koltzow M., LaCasce J., Lee C.M., Lavergne T., Lydersen C., Nicolaus M., Nilsen F., Nøst O.A., Orvik K.A., Reigstad M., Schyberg H., Seuthe L., Skagseth Ø., Skardhamar J., Skogseth R., Sperrevik A., Svensen C., Søiland H., Teigen S.H., Tverberg V. \& Riser C.W. 2011. Closing the loop-approaches to monitoring the state of the Arctic Mediterranean during the International Polar Year 20072008. Progress in Oceanography 90, 62-89, http://dx.doi. org/10.1016/j.pocean.2011.02.010.

Myklestad S.M. 2000. Dissolved organic carbon from phytoplankton. In P.J. Wangersky (ed.): Marine chemistry. Pp. 111-148. Berlin: Springer.

Opsahl S., Benner R. \& Amon R.M.W. 1999. Major flux of terrigenous dissolved organic matter through the Arctic Ocean. Limnology and Oceanography 44, 2017-2023, http:// dx.doi.org/10.4319/lo.1999.44.8.2017.

Romankevich E. \& Vetrov A. 2016. Organic matter. In J. Harff et al. (eds.): Encyclopedia of marine geosciences. Pp. 596-602. Dordrecht: Springer.

Sipler R.E., Kellogg C.T.E., Connelly T.L., Roberts Q.N., Yager P.L. \& Bronk D.A. 2017. Microbial community response to terrestrially derived dissolved organic matter in the coastal Arctic. In J. Dinasquet et al. (eds.): Microbiology of the rapidly changing polar environments. Pp. 184-198. Lausanne: Frontiers.

Vetrov A.A. \& Romankevich E.A. 2004. Carbon cycle in the Russian Arctic seas. Berlin: Springer.

Vetrov A.A. \& Romankevich E.A. 2014. Primary production and fluxes of organic carbon to the sea bed in the Eurasian Arctic seas, 2003-2012. Doklady Earth Sciences 454, 44-46, http://dx.doi.org/10.1134/S1028334X14010073. 